\title{
Strategy for Improving the Quality of Public Services at PDAM Company Tirta Mangakaluku Palopo City
}

\author{
Syahruddin Syah', Jusmia Paseba² \\ Public Administration Study Program, Faculty of Social and Political Sciences \\ Universitas Andi Djemma \\ Email: ekosyahrir67@gmail.com ${ }^{1}$
}

(Received: 28 July 2020; revised: 14 August 2020; published: 23 September 2020)

\begin{abstract}
This research is motivated by a problem in which the Regional Water Company Tirta Mangkaluku Palopo City has received many complaints from customers in providing services starting from water rates, water quality that is still cloudy, abnormal water discharge and water that does not flow at all. In general, this study aims to determine how the strategy of the Tirta Mangkaluku Regional Drinking Water Company in improv the quality of public services. Palopo. This research uses descriptive qualitative research type. The focus of this research is on the service strategy of PDAM TM Palopo City. Data collection techniques are interviews, observations, and also based on documents from the Regional Water Company Tirta Mangkaluku Palopo City. The results showed that the strategy for improving the quality of public services at the Tirta Mangkaluku Regional Drinking Water Company in Palopo City on the core strategy, consequences, customers and control was adequate in realizing public services but the cultural strategy had not provided the quality of public services in accordance with the expectations of stakeholders, because the community still continues to complain about the attitudes, behavior and services provided to the community as customers.
\end{abstract}

Keywords: Strategy, Public Service Quality

Copyright (C) 2020 Universitas Negeri Makassar. This is an open access article under the CC BY license (http://creativecommons.org/licenses/by/4.0/)

\section{INTRODUCTION}

Administration is the whole process of cooperation between two people or humans or more which is based on certain rationalities to achieve predetermined goals (Siagian, 2013). So, in its implementation, the most important thing in administration is the running of activities that are planned and driven by administrative people. Therefore, administrative activities are also inseparable from the management process so that it can be said that management is the essence of administration and leadership is the core of management.

Strategy is a series of fundamental decisions or actions made by top management and implemented by all levels of an organization in order to achieve the organization (Sondang P. 
110 | Pinisi Business Administration Review

Volume 2 Nomor 2, September 2020. Hal 109-106

Siagian, 2009). In strategy activities, there are several levels of strategy consisting of enterprise strategy, corporate strategy, business strategy, and functional strategy (Salusu, 2000). To the community.

Public service is any activity carried out by the government for a number of people who have every profitable activity in a group or unit and offer satisfaction even though the result is not tied to a physical product (Sinambela, Poltak, 2016). The types of services consist of: government services, development services, utility services, clothing services, and community services (Syahiruddin SYAH, 2018). Of the various types of services, one of the most important parts of community life is services related to utilities for the community which involve the provision of clean water, electricity, telephones and transportation. Functionally, public services are provided by public service providers in accordance with their duties, functions and authorities. In the application of public services, there is a scope of public services, namely: Political dimensions concerning citizen relations, economic dimensions concerning public service financing, social dimensions which discuss policies to serve the public and dimensions of communication organizations concerning organizational performance, public services, work standards, implementing apparatus, and communication between recipients (Achmad Nurmandi, 2010).

The strategy in improving the quality of public services is one of the bureaucratic refutation agendas that starts from the bad factual conditions that the quality of service is partly determined by the quality of the attitudes of government officials. (Pelham, 1988; Perry, 2015; Peterson \& Jun, 2009; Ramparsad, 2005; Zainal \& Farwita, 2019; Zainal, Guntur, Rakid, \& Farwita, 2018). Strategy is very important to expand market access (Henni Zainal, Parinsi, Indonesia, Hasan, \& Makassar, 2018). In improving the quality of public services there are five strategies that can be used, namely: Core strategy, Consequences strategy, Customer strategy, Controlling strategy, Culture strategy (Osborne. David, 1992)(Zainal et al., 2020). Based on the description of the strategy in relation to improving public services, the researcher decided to choose the object of the Mangkaluku City of Palopo Drinking Water Company which is one of the companies that runs on public services to the community, in this case in relation to the provision of drinking water and clean water. The purpose of this study was to determine the strategy of PDAM Tirta Mangkaluku Palopo City to improve the quality of public services.

\section{RESEARCH METHOD}

The design used in this research is qualitative research, namely conducting direct interviews so that it can be known in detail and in depth to obtain an overview and be able to understand and explain related to the strategy for improving the quality of public services at the local water company Tirta Mangkaluku Palopo City. The informants in this study were the Employ PDAM Tirta Mangkaluku Palopo City and the Palopo City Community. The type of data used in this study is qualitative data, namely data obtained by researchers directly from the research location through observation and interviews, namely in PDAM Tirta Mangkaluku Palopo City, while secondary data is obtained through journal / internet searches. Data collection techniques are by means of research. Field obtained through primary data collection such as observation, interviews, documentation and secondary data collection such as supporting data, namely archives / existing documents or literature related to the research 
Syahruddin Syah; Strategy for Improving... |111

subject. The methods used are observation, interviews, and documentation. Observation, make direct observations and study matters related to direct research at PDAM Tirta Mangkaluku Palopo City. Interview, conducting interviews with the officials of PDAM Tirta Mangkaluku Palopo City and the Palopo City Community who have the authority in relation to the problems studied. Documentation, namely by obtaining data by reading and studying books, journals or literature that are related to strategies and public services.

\section{RESEARCH RESULTS AND DISCUSSION}

Regional Drinking Water Company is one regional owned business unit, which is engaged in the distribution of clean water for the general public. Regional Drinking Water Company is a regional company that provides clean water supply that is supervised and monitored by the Regional Executive and Legislative Apparatus. In providing a good service to customers or the community, of course, the agency has a method or strategy to satisfy the customer. From the strategy in providing a service the writer uses the theory of Osborne and Plastrik (2001: 49) which formulates 5 strategies in improving the quality of public services, namely: core strategy, Consequences Strategy, Customer Strategy, Strategy Control (Controlling Strategy), Cultural Strategy (Culture Strategy). The results of this study are interviews and observations made by the author at the Tirta Mangkaluku Regional Drinking Water Company, Palopo City.

Based on the indicators used in this study, the results of the research were obtained from the results of interviews for the core strategy. Based on the theory of clarity of vision, the mission is linked to the results of the interview. The Subdif of Complaints PDAM has run the company in accordance with the vision, mission. All planning is carried out before operating for customer satisfaction and improving human resources so that operations are in accordance with customer needs.

Abdi Majid S.sos as Subdif of Complaints of PDAM Tirta Mangkaluku City of Palopo revealed: "I as a sub-division of complaints who always find and even process customer complaints with other staff, we are always on standby, even within hours of our complaints we process for the convenience of customers or the community accordingly. with our aim to improve services to the community and make the community and employees feel like they belong to the company, regardless of who the water users are, from where, what position we immediately improve when they submit a complaint. (Interview on 27 February 2020).

Based on the theory of the interview results above related to the core strategy theory, customer satisfaction is the main thing for PDAMs in providing services that are based on the goals, visions, missions of the PDAM and implementing the quality of customer information on the service system. Furthermore, the research results obtained from the interview results for the Consequences Strategy. This strategy aims to implement the consequences for employee and organizational performance. This second strategy determines the right incentive system. Researchers conducted interviews with H. Hamid SN, ST, M, Si. As the Operational Director for the Regional Drinking Water Company, Tirta Mangkaluku, Palopo City. By giving consequences to our employees who make mistakes by looking at the form of mistakes or violations committed, if the violation is minor we give a warning if it has been given a warning 
and is still committing it then we will give a sanction according to his actions. And our employees who have the skills and skills with high integrity in performing a performance also get intensive but in the form of wages and even a promotion, where employees who perform well are given the opportunity to test their skills and intelligence on manager selection or manager systems. In the past, we used the appointment system as the director's priority, but now we provide opportunities for employees who have good performance with high skills and intelligence. (Interview on 27 February 2020).

Based on the theory of the results of the interview above, it is related to the theory of the consequence strategy of implementing Rewards and Punishment aimed at improving the quality of employee discipline so that PDAM employees are able to compete with other PDAM employees, so that services continue to be prominent. The research results obtained from interviews for Customer Strategy. In this indicator section the researcher will explain whether service procedures are in accordance with the public service system and how to manage customer complaints and provide facilities and infrastructure to support services to customers. To explain the concept above, the researcher conducted an interview with Akbar ST. As a distribution staff at PDAM Tirta Mangkaluku Palopo City: "When the complaint department reports a water condition that is not smooth or does not flow at all, we as the distribution division immediately record the location and house that made the complaint and order the field department to check and correct the complaint". (Interview on 27 February 2020).

Based on the theory of the results of the interview above, it is related to the customer strategy theory in the distribution sector when the complaint field is completed with existing procedures. Furthermore, the research results obtained from interviews for the Control Strategy (Controlling Strategy), In this indicator section the researcher will explain how the PDAM TM Palopo City empowers employees, is independent and innovates which has an impact on public confidence in the services provided. To explain the above concept, Then the researcher conducted an interview with Suliyati as the staff of the Complaints section of PDAM Tirta Mangkaluku City of Palopo, who revealed: "In carrying out this complaint service, of course, as a staff member, I have attended trainings to be able to work in this field properly because I made a change of course through learning experience. What we get from trainings ". (Interview on 27 February 2020). And that statement is supported by the results of an interview with Arnawati as the recipient community of PDAM Tirta Mangkaluku City of Palopo: "I have complained about PDAM services before but after they made a change when I complained to them they quickly responded and fixed my complaints, so I trust them in responding to my complaints".

Based on the theory of the results of the interview above, it is related to the customer strategy theory in the distribution sector when the complaint field is completed with existing procedures. The research results obtained from interviews for the Cultural Strategy. In this indicator section, the researcher will explain how the PDAM TM Kota behaves towards the community whether it implements an attitude that is in accordance with the $5 \mathrm{~S}$ organizational culture (Smile, greetings, greetings, politeness and courtesy as well as people's views on the employee's mindset. To explain the above concept, the researcher conducts an interview with Maman as a recipient of PDAM Tirta Mangkaluku City Palopo service revealed: "The water channel is not clear, which results in the bathtub being cleaned almost every day, and during the 
Syahruddin Syah; Strategy for Improving... |113

rainy season the water sometimes doesn't flow. This worries us, and I as a customer I really hope for a change without continuing complaints. Must monitor the cleanliness that is distributed more "(Interview on February 27, 2020). Based on the theory of the results of interviews with the two members of the community above in accordance with the indicators of cultural strategy theory, the community is still anxious about the attitude of employees who pay less attention to services given right, they did a review when complained (Hersey, P., dan Blanchard, 1992; Nel Arianti, 2014; Robbins., 2002; Susanto, A.B., 2006).

Based on the results of the interviews obtained, the researcher concluded that the strategy for improving the quality of public services at PDAM TM Palopo City seen from the indicators of the Cultural Strategy of employees in providing a service has not implemented the attitudes and behaviors that are expected by the community as stakeholders to the maximum service they provide, they are quick to respond but at time of complaint only, not when the first service was delivered. But the PDAM has made this a reference and continues to improve services from the mistakes that have occurred.

Based on the theory of Osborne and Plastrik (2001: 49), the purpose of the Cultural Strategy is to change the behavior, feelings, and ways of thinking of civil servants. This strategy aims to put the values, norms, attitudes and expectations of stakeholders in accordance with the goals of the organization, its intensive system, its accountability system and the power structure system. Related to the indicators of the behavioral culture strategy of PDAM TM Palopo City employees, they have not maximally implemented the culture of attitudes and behavior towards the services provided to the community, because they always find complaints of complaints from the services they provide or have not matched the expectations of stakeholders, in this case the community so that the community think their services are inadequate, for example water rates that are not in accordance with customer usage, water not flowing, the level of water cleanliness and the attitude of employees who are less open and friendly to customers who visit the office, these are experienced directly by researchers, when researchers make observations at the research location, namely PDAM TM Palopo City. The cultural strategy is one that supports the convenience of a service and can encourage all structures to improve performance for both the short and long term, so that the services provided do not always find complaints which then become an assessment of poor performance. So culture is one of the main things in supporting service quality because culture is inherent in the company's human resources and human resources as the driving force of the company.

This is used as an evaluation to fix services from errors that occur so that the services provided are maximal. From these mistakes, they strive to be thorough in minimizing customer payment rates and fix public complaints about the smooth running of water. One of their efforts to monitor community complaints is through the media telephone, social media, they make these media a place for complaints, suggestions or constructive criticism.

\section{CONCLUSION}

The results of the research and discussion in the previous chapter, it can be concluded that the Strategy for Improving the Service Quality of the Regional Drinking Water Company of Tirta Mangkaluku City of Palopo is seen from the core strategy indicators of the leadership, and their staff have carried out a service or task in accordance with their respective roles or 
114 Pinisi Business Administration Review

Volume 2 Nomor 2, September 2020. Hal 109-106

functions and sticking to the goals, vision and mission of the Company. And making the community or customers a priority according to the goals of the Palopo PDAM PAM in order to achieve an increase in the quality of public services as well as on the Consequence Strategy indicator, the Regional Water Company Tirta Mangkaluku City of Palopo has implemented consequences on employee performance towards the organization, the consequences are able to encourage employees to be more disciplined in obeying the rules and being able to provide proper service to customers. This is used as an evaluation to fix services from errors that occur so that the services provided are maximal. From these mistakes, they strive to be thorough in minimizing customer payment rates and fix public complaints about the smooth running of water. One of their efforts to monitor community complaints is through the media telephone, social media, they make these media a place for complaints, suggestions or constructive criticism.

\section{BIBLIOGRAPHY}

Achmad Nurmandi. (2010). Manajemen Pelayan Publik. Yogyakarta: PT.Sinergi.

Henni Zainal, U. I. T., Parinsi, W. K., Indonesia, S. P., Hasan, M., \& Makassar, U. N. (2018).

The Influence Of Strategic Assets And Market Orientation To The Performance Of Family

Business In Makassar City , Indonesia, 17(6), 1-9.

Hersey, P., dan Blanchard, K. (1992). Manajemen Perilaku Organisasi. Jakarta: Erlangga.

Nel Arianti. (2014). Pengaruh budaya organisasi terhadap kinerja pegawai. Jurnal Manajemen

Dan Bisnis, 14(2).

Osborne. David, dan T. G. (1992). Reinventing Government: How the Enter Preneur Spirit is

Transforming Public Sektor. Massachuttes.: Addison-Wesley Publishing Company.

Pelham, A. M. (1988). Influence of Environment, Strategy, and Market Orientation on Performance in Small Manufacturing Firms, 2963(98).

Perry, J. L. (2015). Public Service Motivation Research: Achievements, Challenges, and Future Directions, (October), 692-699. https://doi.org/10.1111/puar.12430.We

Peterson, R. T., \& Jun, M. (2009). Perceptions on Social Responsibility. Business \& Society, 48(3), 385-405. https://doi.org/10.1007/BF01294227

Ramparsad, R. (2005). A strategy for teacher involvement in curriculum development, 21(4).

Robbins. (2002). Perilaku Organisasi. Jakarta: PT. Indesk Kelompok Gramedia.

Salusu, J. (2000). Pengambilan Keputusan Stratejik. Jakarta: Gramedia.

Siagian, S. P. (2013). Manajemen Sumber Daya Manusia. Jakarta: Bumi Aksara. 
Syahruddin Syah; Strategy for Improving... |115

Sinambela, Poltak, L. (2016). Manajemen Sumber Daya Manusia. Jakarta: Bumi Aksara.

Sondang P. Siagian. (2009). Kiat Meningkatkan Produktivitas Kerja. Jakarta: Rineka Cipta.

Susanto, A.B., G. P. (2006). Strategi Organisasi. Yogyakarta: Amara Books.

Syahiruddin SYAH, A. M. T. (2018). Pengantar Ilmu Administrasi Publik. Makassar: Andi Jemma Press.

Zainal, H., \& Farwita, S. (2019). An Analysis of Customer Satisfaction in Ambon City Water Supply Company, (Iconetos), 65-71.

Zainal, H., Guntur, M., Rakid, M., \& Farwita, S. (2018). Human Resource Development Strategy Through Education and Training, 3(3), 26-30.

Zainal, H., Rakib, M., Ashar, A. I., Manda, D., Sose, T., \& Setitit, I. (2020). Strategy of human resources development in improving performance Apparatus in the Bone Regency Regional Inspectorate, 2(1), 35-44. 
116 | Pinisi Business Administration Review

Volume 2 Nomor 2, September 2020. Hal 109-106 